JOURNAL OF AWARENESS

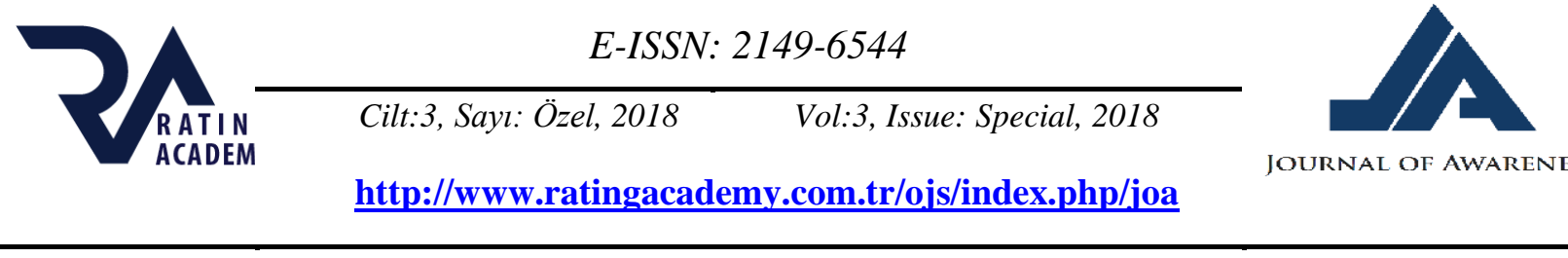

\title{
ASPECTS OF LANGUAGE KNOWLEDGE IN PRECHOOLERS*
}

\author{
Department of Education Faculty of Education and Philology \\ University "Fan S. Noli", Korçë, ALBANIA \\ E-mail: rozaag@hotmail.com
}

Laura AGOLLI

Master in Political Science and Public Administration

Istanbul University, Istanbul, TURKEY

E-mail: laura.agolli@ogr.iu.edu.tr

\begin{tabular}{l|l}
\hline ARTICLE INFO & \multicolumn{1}{|c}{ ABSTRACT } \\
\begin{tabular}{l|l} 
Keywords: \\
Preschool child, language \\
knowledge, reading skills, \\
oral habits, phonology, \\
lexical.
\end{tabular} & $\begin{array}{l}\text { Language development in the years of preschool education is the dimension of the } \\
\text { cognitive sphere. As the development of many particles, the language skills of pre- } \\
\text { school children have passed the trials by creating a stable language base. } \\
\text { Phonology, morphology, semantics, syntax and pragmatics of a language are } \\
\text { taught and embedded in a continuous interaction. } \\
\text { Using in a correct way the grammatical and syntax language, the discovery of } \\
\text { some basic rules of grammar, the correct use of words with regular language } \\
\text { skills, indicates that the child is advancing in the use of language by norms, easily } \\
\text { passing the message to the listener. } \\
\text { DOI: } \\
\text { The intellectual advancement of the child is limited if he is unable to read. The } \\
\text { reading habits are attained using different methods, such as like: The method of } \\
\text { the alphabet; Syringe method; Method of speech; The phrase method; Sentence } \\
\text { method; The narrative method; The method of phonology. The expansion of } \\
\text { phonological and lexical inventories will have an impact on the child's future, so } \\
\text { it is important that he be helped to own the language and vocabulary introduced } \\
\text { through the books. } \\
\text { The language has a social use that includes not only words as separate choices } \\
\text { but also the message to be sent. Consequently, when children hear a new word } \\
\text { they are first interested in discovering what this means in the mind of the speaker, } \\
\text { thus narrowing the possible meanings of the word used. The linguistic } \\
\text { development of the preschool is a very complicated and multifaceted process } \\
\text { through which the mind turns the spoken language into a concrete sense. }\end{array}$
\end{tabular}


The main place in the process of enlightening people's minds is the discourse as the first and the foremost form of communication, as a behavior that is donated to human beings biologically, as a vital activity. Through discourse, information is acquired, understood and processed more easily. To convey our message during the lecture, language as the structural model of the system we use helps us [Berzani, 2007].

The language model is alive in the form of words and the structured connection between words and expressions. A wider range of functions performs spoken language than written language. These functions begin with casual occasional conversations and end up with book lectures and so on [Shkurtaj, 2005].

Human co-operation is accomplished through discourse. It is the means through which different activities are coordinated and linked to one another in achieving common and mutual goals. For children, reality and imagination are intertwined to the point that they can give life to things and inflexible. That is why children can talk to a chair, a puppet, or whatever [Mato et al 2002].

The development of spoken language in pre-school children is not simply an expression of the language structure. The development of spoken language includes the development of pragmatic use, in addition to the development of pronunciation, word constructions, expressions, sentences [Idrees, 2010].

Language development of children includes speech and listening through enrichment of vocabulary, grammatical and syntactic knowledge, understanding and spoken language. Growth is achieved and depending on the use of varied words by adults. Using the word in the most varied situations helps the child to enrich his language corpus before using it in the right context. The correct use of grammatical and syntax language, the discovery of some basic rules of grammar, the correct use of words with regular language skills, indicates that the child is advancing in the use of the language according to the norms, easily transmitting the message to the listener [Kamami, 2007].

Before babies say the first word, they are prepared to use the language in many ways. As children grow up, their communication needs also change. Throughout the early years, children develop fluent communication. They have learned a lot about the goals and ways of communication. It is important for adults to support these changes so that children continue to grow as capable communicators. Songs and poems are just one of the ways to promote the child's language development. They help the child understand the pace of language and sentence building patterns.

\section{Writing origin}

Writing is considered as an alternative language tool, giving expression to eternity. Lado (1971) states that writing is the graphic representation of a language. Pictures and symbols, when they fail to form a system representing language units, are not supposed to be writings [Saville-Troike, 2003].

Writing is a universal activity through which authentic communication takes place. Ellbow defines writing as a kind of magic that can be done by anyone involved and believes in his own fairy tale [Elbow, 1981, 1988]. The art of writing is the process of translating abstract ideas into a concrete form. This happens in the process of transforming abstract sounds into concrete characters.

Human inner ideas or discourse is transmitted with precision through the graphs of the language as visible signs that form words and sentences. Consequently, knowledge and information can be saved. Sempson (Geoffrey Sampson, 1985) becomes the supporter of 
everything we said above, saying "Writing is a system for representing spoken language expressions through visible and perpetual signs" [Khosrow-Pou, 2015].

For Bloomfield, "writing is not a language, but simply a way of recording a language through visible signs" [Bloomfield, 1993; 19-21]. By using components, that is, graphs, vocabulary, syntax, etc., writing needs a systematized form, in order to enable the reader to understand it properly.

Children begin to understand that the writing differs from drawing. They are repeated and placed in rows in a certain direction. The child can manage to write through the combination of many skills. The writing process relies on the development of areas that are not specifically related to writing [Idrees, 2010; 59].

Learning to read and write scripts are two important lingual development processes that support each other. Often, children with good writing skills have good reading skills and vice versa. The random dyeing of a two year old is an indicator of writing development. As the muscles grow stronger, children have more control over the scratching, making them linear. About 4 years of age, children make shapes similar to letters, with irregular and random forms. But it is important at this stage to understand that children have the concept of writing, as they differ from drawing.

\section{Global literacy origin}

Reading is a complicated and conscious activity. It uses symbols to absorb visible and invisible meanings and ideas. The child's education is incomplete if he does not gain the ability to read, decipher, interpret, and properly understand a reading material. Therefore, one of the important gates of providing knowledge and knowledge to the world around us is the linguistic and reading habit. Intellectual advancement of the child is strictly limited if he is unable to read [Jenikson, 1973].

Experts in the field of reading have defined it in different ways. For Betts (Emmett Albert Betts), there is no doubt that thinking is a very important aspect of the reading process, hence and has defined it as a thinking process [Betts, 1996].

To create meaning, the process of mutual relations is realized between the symbols of the writer or the writer and the mind of the reader. In this way, Jenikson (Marion Jenikson) and Widdowson (Henry Widdowson) add another dimension to this definition when they say that reading is the act of reaction to the symbols on the paper [Jenikson, 1973]; reading is the process of obtaining linguistic information through the direct reading of the symbols printed on paper, while the information transmitted by the writer or writer through letters cast on the paper is absorbed by the reader. [Kaplan, 2010].

Expressions to read, start long before the child reads the first book. When the young child turns his head to the sound of the parent's voice, he / she begins to pay attention to the language, which will later be read. Behaviors that precede independent reading start very early. For example, younger children can stay up to 7-8 months, and can stutter while stroking the book's figures, and this is an indication that the book is of interest to you. As children enter the age of three, reading-like behaviors begin to appear. These behaviors may include possibly reading or authentic reading. Later the child can "read" a book, retracing it as it has heard from the adult and may be more focused on the reading activity, possibly, especially in preschool age. These are important steps ahead in the development of reading habits [Lleshi; Kulla, 2007].

\section{Reading Methods}


Learning through reading is a conscious process that is taught to acquire knowledge deliberately. Reading habits are gained using various methods, which are categorized as follows:

- The method of the alphabet;

- Syllable method;

- The method of speech;

- The phrase method;

- Sentence method;

- Storytelling method;

- The Phonic Method [Hall, 1983].

Thus, when using the alphabet method, children are taught letters in alphabetical order and then the combination of two or more letters, as well as the combination of words in the sentence. In the case when the syllable method is used, the unit taught to children is the syllable and not the letter. The syllables are used directly and in this way words and sentences are formed through the combination of syllables.

When using word and phrase methods, the unit that is taught to children is the word.

When using the sentence method, the sentence is taught to children.

When using the narrative method, children are taught the tale embodied in four or five sentences, which are illustrated with paintings.

In the case of the use of the method of phonology, it is based on phonology and this is aligned with the method of the alphabet. So, sounds are the units that are taught to children. Each of these methods has its own advantages and disadvantages.

\section{Hearing activity}

Hearing activity plays an important role in the process of learning and acquiring the language. Every barrier to hearing activity affects the linguistic development of other habits. Listening is the first and the main language vocabulary that children adopt. Listening is an extremely complex and multifaceted process through which the mind turns the spoken language into concrete meaning [Brooks, 2013].

During the process of language acquisition, children naturally hear the language spoken around them. So, one year after birth, they begin to deal with hearing activity passively, while, over time, participate actively in the language society they are part of. The researchers have identified three steps in the hearing process, which are: acquisition, processing and definition of meaning [Vasta et.al, 1998].

Three stages or stages of the hearing process have been identified, which are: perception, examination and exploitation [Karaj, 2004].

During the perception phase, children concentrate on the sounds of the language and store them in remembrance, during the screening phase, use words and expressions to make meaningful reproductions that can be stored in memory. The volume of the part you remember depends on language recognition as well as the quality of the signal. Meanwhile, during the final phase, that of exploitation, children uncover long-term memory to connect the already familiar acquaintance by presenting the information stored in the form of schemes.

According to Brown, there are identified eight types of hearing with relevant purpose (Brown, 1986]. In eight types of listening the pre-school child is active and inclusive. 
- Transactional listening: learning new information (for example, the child talks, discusses);

- Interactive listening: Knowing the personal component of the message (for example, happily hears new happenings, reports happening);

- Critical listening: Evaluating reasoning and evidence (for example, giving personal opinions);

- Listening fun: assessing the occasional or integrated aspects of an event (for example, artistically reacts);

- Evaluative listening: information, choice or critical isolation (for example, selects keywords when listening to an occurrence with the sun, moon, stars);

- Selective listening: Selection at a certain time of certain features (for example, phonetic features);

- Intensive listening: capturing details (for example, enhancing vocabulary);

- Extensive listening: capturing the general idea (for example, summarizing the story).

In conclusion, we can say that the knowledge of the child with the language in all its forms, as well as the further cultivation of all language skills are two interdependent phases. The more aware the child is for the language, the better it will use it and the better it is to use, the more sensitive it will have toward its expressive potential. 


\section{BIBLIOGRAPHY}

Berzani, Alketa (2007), Si mësojnë fëmijët të flasin, Edukimi parashkollor, 10, Tiranë.

Betts, E. Albert (1996), A New Area: Reading And Linguistics, Reading Teacher, Vol. 18.

Bloomfield, Leonard (1993), Language, George Allen Of Unwin Ltd, New York.

Brooks, Gavin (2013), Creating Interactive Electronic Materials for EFL Listening Classes, Conference

Proceedings.http://www.academia.edu/9375214/Creating_Interactive_Electronic_Mat erials_for_EFL_Listening_Classes

Elbow, Peter (1981, 1988), Writing With Power: Techniques For Mastering The Writing Process, Oxford University Press, London. http://staff.uny.ac.id/sites/default/files/pendidikan/dwi-budiyanto-spdmhum/ebookscluborgwritingwithpowertechniquesformasteringthewritingprocess.pdf

Hall, Donald (1983), “Four Kinds Of Reading”, Thinking In Writing, redaktuar nga McQuade, D.; Robert Atwan, K., New York.

Idrees, Raiha (2010), Shqipëria lexon, Instituti i Zhvillimit të Arsimit, UNICEF.

Jenkinson, Marion D. (1973), Ways of teaching, në The teaching of reading, redaktuar nga Stranger, R. $\quad$ C., $\quad$ UNESCO, Paris. http://unesdoc.unesco.org/images/0000/000045/004510eo.pdf

Kamami, Pranvera (2007), Zhvillimi gjuhësor, Edukimi parashkollor, 10, Tiranë.

Khosrow-Pour, Mehdi (2015), Encyclopedia of Information Science and Technology, Third Edition, IGI Global, Copyright.

https://books.google.al/books?id=MJd_BAAAQBAJ\&printsec=frontcover\#v=onepage \&q\&f= false

Kaplan, Robert B. (2010), The Oxford Handbook of Applied Linguistics, Oxford University, Press.

https://books.google.al/books?id=nxH0k3UbAvAC\&dq=Applied+Linguistics+7+(3),+ pp.+284-302.\&source $=$ gbs_navlinks_s

Leshi, Majlinda (2007), Gjuha në kopsht, Edukimi parashkollor, 10, Tiranë.

Mato, Erlehta et. al., (2012), Gati për në shkollë, Libri i mësuesit, UNICEF, Tiranë.

Saville-Troike, Muriel (2003), The Ethnography of Communication, Cowley Road, Oxford. https://gumonounib.files.wordpress.com/2010/06/the-ethnography-of-communicationan-introduction-third-edition-by-muriel-saville-troike.pdf

Shkurtaj, Gjovalin (2005), Etnografia e të folurit të shqipes, Botimet Toena, Tiranë. 